\title{
Nepal-China-India Relation: A Geostrategic Perspectives
}

\author{
Kabi Prasad Pokhrel \\ Professor, Central Department of Geography Education, CDGE, TU, Nepal \\ drkabipokhrel@gmail.com
}

\begin{abstract}
Article History

Received August 16, 2020

Accepted November 10, 2020

This paper is an attempt to trace out the Nepal 's China-India relation in the context of dynamic changes of powerful nations of the world as well as emerging regional countries. Existing international relation of Nepal is needed tactic diplomacy to take maximum economic and technological benefits

\section{Keywords}

Geostrategic locations, from global major powerful countries and emerging powerful nations, trans-Himalayan route, political economy, and tactic diplomacy. regional countries. The existing foreign relation of Nepal and future adaptive strategies have been discussed using qualitative approach. By reviewing and synthesizing ongoing initiations of present government at the global, regional and national level, paper drew the conclusion to maintain balance relation between and among the north -south two neighbors including super power of the world. Paper further emphasized

Corresponding Editor Ramesh Raj Kunwar kunwar.dr@gmail.com to adopt among equals foreign relation strategy to take benefits from the emerging powerful countries in the Asian region.
\end{abstract}

Copyright@2021 Author

Published by: APF Command and Staff College, Kathmandu, Nepal

ISSN 2616-0242 


\section{Introduction}

Geostrategy considers in a tactical military sense, political sense and culturally defined territorial sense in terms of spatial distribution of resources, peoples and geo-physical systems. Cohen (2010) viewed that the geopolitical structure, its role and capacities as the geopolitical forces it shapes the international relation system and diplomatic tactics of any nations. Geopolitical existence of Nepal has the ability to influence world politics due to its geographical location as functioned as the turning table of east Asia and south Asia and deserves the strategic importance for the super power nations of the world. The politics and economic interest of powerful nations such as United S of America (USA), China, European Commission (EU) and India, thus, directly indirectly determine the foreign policy of Nepal by the greater involvement of powerful nations in macro and micro management. It is; therefore, Nepal's foreign relations are driven by the politics of powerful nations who perennially strive to maximize their power to achieve their national interests. Power maximization involves a combination of economic growth, military modernization and diplomacy. During periods ofmomentous change, it is often noticed that the status-quasit powers try to prevent others from advancing to a higher level while aspiring powers seek to counter these efforts with all the resources at their disposal. Ever since the end of the Cold War, the world has been passing through a period of power transition and the center of gravity of international politics has been shifted to Asia because of the economic and military prowess of the two aspiring powers i.e. China and India. In this context, the US, as a status quo power, is perceived to be pursuing a twin policy of diplomacy of cooperation and containment to deal with them. China and India, on the other hand, given their geographic constraints have been trying to sustain their rise by developing cooperative and friendly relations with their neighbors i.e. Nepal, as well as cooperating with each other at the global level. But as they are located in the same region, there is also competition between the two for resources and strategic influence (Pant and Rie, 2018).

This race for power maximization among nations has implications for the Himalayan states Nepal and Bhutan due the strategic location as they are situated at the meeting point of East Asia and South Asia. The Himalayas have long been a natural barrier between Indian and Chinese civilizations which are great civilizations of Asian region. Both civilizations have treated it as their protector against external and mutual threats. However, the myth of Himalayas as the natural protector proved wrong when China and India fought a war in October 1962. The invention and application of modern technology brought about a new but peculiar scenario that led to significant change in the nature of warfare. Thus, the concept of security was redefined with the changing needs and demands of global politics. Following the success of anti-colonial movement in China and independence of India, the Himalayan region drew the attention of major powers from other continent(s), whowere involved in ideological rivalry. This caused concern for both China and India. Given their geographical proximity, both countries integrated their part/portion of the Himalayas as theirnatural frontier. This resulted in competition forextension of influence in the proximate neighborhoods for strategic advantage. Both are looking for solutions on the disputed borders, make unilateral claims on certain parts as their exclusive zone of influence. A sense of competition and mutual suspicion has intensified further to control 
the Himalayan frontier in both countries and military infrastructure developments in Tibet. India is the only major power located in the south of Tibet and it can be implied that the military build-up in Tibet is possibly targeted (Dixit,2010).

Regarding the rising influences and interest of China and India on Nepalese politics with their direct and indirect involvement in macro and micro level management of daily business of government, this paper has an attempt to discuss the impacts and opportunities in Nepalese political economy from the emerging diplomatic relations of north and south neighbors as well as westerns by intensively reviewing the available literature on international relation, diplomatic tactic and existing foreign policy of Nepal.

\section{Nepal's foreign policy}

The diversification of Nepal's foreign policy in the early 1960s was an attempt to ensure regime security and its territorial integrity against perceived threat from its neighbors and also to reduced its dependency with India. The external powers took advantages of it and motivated partly because of their own interest to have a foothold in this geostrategic location. However, geography of Nepal remains a constant and a major determinant of nation foreign policy. Further, there have been occasions when some Nepali leaders misread the development in the region and beyond, and tried to use external powers against regional actors.

Nepal has its relationship with the Western countries to meet its developmental needs. In the past, this had also enabled to counter balance India's influence. Until the early 1970s, the US was the top foreign aid donor to Nepal. In the post-Cold War period, the US influence on Nepal's domestic politics was diminished as it shifted its focus to other regions of the world. Nepal further caught US direct interventions due to the rise of India and China as the emerging powers. Now a days the influence of US on Nepalese politics is channeled through Indian strategies because US considers India as a representative to control the influence of China in Asian region. This strategy has been functioned especially after Maoist insurgency in Nepal. The US tried to help the king in his anti-Maoist counter insurgency operations. While the political situation changed in 2005 and favored the democratic forces, the US gradually came to recognize (reluctantly until 2009) India's efforts towards peace initiatives and political stability in Nepal. Thus, US considers India as a reliable partner in South Asia onward 2012 and it enunciated it rebalance policy towards Asia. Since the third Indo-US strategic dialogue in 2011 it was more pronouncedly sought to partner with India to address common challenges in the region. The Himalayas are strategically important for countries like Nepal and Bhutan. These small states act as partial geographical buffers between India and China separated by hundreds of miles and they are also more dependent on their southern neighbor India for easy access to sea for trade with other countries. It id therefore, between these two big emerging power countries Nepal has been attracted the greater attention of the external powers (Nayak,2012). 
Historically, Nepal has remained a strategic location for big powers since the Cold War. It has also always figured prominently in the regional power politics centered around the Himalayan region. In return, Nepal took advantages from major/external powers by their presence on its territory to counter balance the influences of its two neighbors and also to secure its territorial integrity. Despite that Nepal's foreign policy is mostly focused on maintaining balance between its two bigger neighbors. As regards the US; it has never been a direct threat to Nepal, but Nepal expects it not to pressurize Kathmandu over the Tibet issue. Ever since the beginning of diplomatic relations between Nepal and the US, the latter has been mostly considered as protector of the former in case of any kind of military threat and political interference from China and India. Regarding this, Nepalese elites are supposed that the US will never be able to ignore Nepal's geopolitical location due to China and India factors. China also cannot neglect Nepal as long as the Tibet issue and its border disputes. Nepal's strategic location makes it natural for external powers to take interest in its domestic as well as foreign policy. It is also considerable for the sense of insecurity from the neighbors and occasional uneasy relations with them. It is, therefore, the 10years long spell of Maoist insurgency and the prolonged periods of political uncertainty of Nepal were attracted the attention of external powers for many years. Nepal has assumed even greater salience for extra-regional powers, particularly the US, the UK, and the European Union since the Jana Andolan-II initiated the difficult process of political transition in Nepal from monarchy to democratic republic (Sigdel,2018).

Amidst tumultuous political developments in Nepal, these powers have made efforts to secure their strategic objectives, which might have also, directly or indirectly influenced the political transition. However, their interests in Nepal do not make their engagement a one-sided affair. It is also true that Nepal needed their support to overcome its economic challenges, particularly when India as a dominant partner in Nepalese economy was not in a position to deliver by itself. At a strategic level also, Nepal has been seeking the support of external powers to neutralize the interference of its neighbors in its internal affairs ever since its formation as a sovereign entity. Some observers in Nepal note that for Kathmandu, US influence could be used to counter undue outside influence on the part of India and China.

\section{China's approach to South Asia}

While the Chinese approach to South Asia has been largely centered around India and Pakistan. Later, Nepal has begun to figure prominently in its foreign policy outlook. This region gets special attention in Chinese policy for its perineal friendship and trusted ally. Pakistan, as well as its global economic competitor India both are located in South Asia. Ever since the economic reforms in 1991, India has been emerging as a global competitor for China. A series of successful tests on Inter Continental Ballistic Missiles (ICBMs) by India had raised eyebrows in China among scholars and top leaders about Indian technological progress and, thus China has recognized India as an important factor in Asian politics. Further, the 2005 India-US civil nuclear deal, its pro-active foreign policy in international forums and military modernization have placed India at the center-stage of global affairs. In view of the competition for influence between the two at the regional and 
global levels, it is logical that China wants to keep India tied up in internal and regional matters in order to hamper its global ambitions. Ideologically, also the world's largest democracy, i.e., India is located in this region and China perceives that democratic forces (the US, India and Japan) led by the US, are ganging up against it. As a result, China has made major shifts in its foreign policy towards South Asia since 2000. This was visible after 2005, as China became increasingly concerned about India's expanding strategic ties with the US. The presence of Tibetan refugees in India also added the concerns. In fact, Chinese President Hu Jintao, during his visit to Delhi in March 2012 had discussed the possibilities of India participating in any Western containment strategy with regard to rebalancing role in the Asia Pacific region. Chinese leadership has refocused its attention on increasing its influence in the South Asian neighborhood vis-à-vis with a view to balance perceived American strategy to contain China by strengthening its partnership with India. China is thus continuing its policy of endearing itself to the South Asian countries. China as regularly sent political, economic, military and academic delegations to India's neighboring nations (Donnell,2018).

\section{China's Nepal policy}

China is in favor of a powerful, stable and neutral government in Kathmandu with no matter of ideology. Due to people-centric diplomacy in Nepal, it seems China does not want any confrontation at this moment in this region. For the time being, China prefers to concentrate on developmental programs in its western region.

In the short-term, China wants to continue its diplomatic engagement in Nepal as part of the comprehensive partnership policy at various levels to keep external forces away from the Tibetan refugees' issue. For its long-term benefit Beijing will expand its economic engagement and people to-people relations with Nepal. Moreover, Chinese policy towards Nepal is expected to acquire greater importance in the coming days both because of the twin factors of Tibet and India, and its official emphasis on external periphery.

Geographically, Nepal locates as the southern gateway to Tibet and has closer economic and cultural linkages with Tibet than China since times immemorial. For China, Nepal is a geographic and cultural buffer between Tibet and Tibetan refugees living in India. Beijing fears that Nepal can use by other powers as a frontline state to challenge China's security interests. It suspects that the CIA of US and Indian intelligence agencies(RAW) support Tibetan refugees who are trying to cross into China and Himalayan Mountain range not only always provides a natural defense against infiltration. Some Chinese analysts are in agreement with Maoist leaders that the US agenda in Nepal is basically designed to encircle China. Wang Hongwei, a Chinese expert on Nepal, believes that India and the US are using Nepalese territory to act against China. Expressing China's security concerns, in May 2001, the Chinese ambassador to Kathmandu confirmed that China had a vital interest in securing its strategic southern border by nurturing a credible relationship with Nepal. Tang Jiaxuan, former Foreign Minister of China commented on the deepening political crisis and the role of external forces in Nepal and he mentioned that Beijing has always stuck to the approach of non-intervention towards Nepal's inside affairs, fully respecting 
any model of national development that the Nepalese people chose. Recently the visit of Chinese president Xi Jinping in Nepal further inspired to interconnect with China in the counter balance with India in terms of Nepal's physical infrastructure development and being a beneficiaries from the Belt Road Initiative(BRI) or Silk Road mission of worldwide market connection for Chinese goods. This initiation of China clearly indicates to size down the political influence of India on Nepalese political economy. The active involvement of current Chinese Ambassador in ruling party internal dispute settlement also shows the high interest of China to make determinant roles on Nepalese politics for minimizing the role and influence of India and western countries. Some analysts also suggest that even if China does not expressly mention the role of external forces in Nepal, it is insecure about India's leverage in Nepal as well as the influence of the United States, the United Kingdom, and the European Union. Therefore, China always looks for a credible nationalist force in Nepal, amenable to its influence, for political stability. It also consistently emphasizes that the government of Nepal must stick to the one- China policy and should not allow Tibetans to indulge in any kind of anti- China activities (Ghimire, 2012). China sees Nepal as a strategic location for its geo-political objectives in South Asia. In Chinese strategic perception, Nepal can be utilized by regional powers like India if China fails to maintain or institutionalize strong relationship with Nepal.

Besides, the Chinese experts believe that Nepal is crucial from Beijing's security perspective because of the frequent protest movements and vulnerable conditions in Tibet. In Chinese calculation, having good relations with Nepal can help it to curb Tibetan movements and keep a vigilant eye on the Tibetan protests and activities. Thus, Tibet factor remains primary security issue for China in Nepal and possibility for greater trade and commercial contacts with Nepal has also been the principal objectives of China's recent policy towards Nepal. Trade has continued to expand between China and Nepal over the years, but importantly, China has also inked vital hydro power plant projects with Nepal. For example, China has recently signed a $\$ 1.6$ billion agreement to develop the hydro power plant in Nepal which is of almost 760-Mega Watt, known as West Seti project. This is vital from China's perspective as to be the principal country in Nepal's hydro power and water projects till recently. In short, the Chinese policy towards Nepal consists of both political and economic objectives, targeted at larger South Asian politics and goals. In return, Nepal has equally shown greater support and affiliation with China in the broader South Asian politics. This further clarifies that Nepal's open support for China's application for observer status in SAARC. However, this should take seriously by Nepal due to a neighboring South Asian country, and China shares larger security and political interests with Nepal.

From the economic point of view, overall, China is the second largest trading partner of Nepal after India. Therefore, China's policy towards Nepal has been different from its policies towards the other South Asian countries. China also has three major strategic interests in Nepal: (i) containing Tibetan refugees in the south of the Himalayas and controlling their anti-China activities; (ii) neutral lising India's influence in Nepal and setting up a pro-China regime in Kathmandu, for which China has scaled up its engagement in recent years and has also taken soft diplomatic measures, i.e. people-to-people contacts, cultural relations, scholarships for students, economic aid and spread of Chinese Confucianism by setting up Confucius Institutes in Nepal; and (iii) investing in strategically important infrastructure projects like airports and important highways (Muni,2011). 
From the economic point of view, overall, China is the second largest trading partner of Nepal after India. Therefore, China's policy towards Nepal has been different from its policies towards the other South Asian countries. China also has three major strategic interests in Nepal: (i) containing Tibetan refugees in the south of the Himalayas and controlling their anti-China activities; (ii) neutral lising India's influence in Nepal and setting up a pro-China regime in Kathmandu, for which China has scaled up its engagement in recent years and has also taken soft diplomatic measures, i.e. people-to-people contacts, cultural relations, scholarships for students, economic aid and spread of Chinese Confucianism by setting up Confucius Institutes in Nepal; and (iii) investing in strategically important infrastructure projects like airports and important highways (Muni,2011).

\section{India toward Nepal}

There are historical reasons that explain the dynamics of the Nepal-India bilateral relationship. To maintain a sphere of influence, India needs sufficient soft power, as well as hard power, along with the confidence to act. Pande (2011) argued that managing a sphere of influence is not only a function of telling others what to do but being able to expend resources that deny space to competitors. The former Prime Minister of Nepal Kirti Nidhi Bista said that India made him (PM Bista) lose his temper because during those times when India was economically insignificant, it still had undue demands over Nepal. A combination of economic limitations, India's political manipulation, Chinese inroads, and the outreach of extra-regional powers to Nepal gradually increased its desire to diversify relations. Such ambitions havebeen thecentralelementof successive governments in Nepal, leading to increased friction with India (Shrestha,2014).

Indeed, the nature of India-Nepal relations has always been a mixed bag. Due to its provisions and protocols, the 1950 treaty quickly became controversial and set the conflictive tone of the bilateral relationship. The provisions of the 1950 Indo-Nepal Peace and Friendship Treaty (1950 Treaty: Article 5, Letter of Exchange: Article 2, Indo-Nepal Security Cooperation Agreement, 1965: Article 5), constrained Nepal as an ally and a state under India's security umbrella. In 1988, King Birendra's decision to purchase anti-aircraft guns from China prompted then Indian Foreign Secretary to warn Nepal of its existential uncertainty. Over the years, the incompatibility between the two countries only worsened in various domains (Rajan,2018).

\section{Implications for India}

China's active outreach to Nepal in recent years has been partly prompted by India's increasing force posturing along its border, which, in the first place, was in response to China's activities along the border. Interestingly, the timing of former PM Manmohan Singh's government considering border-force enhancement for defensive purposes roughly coincided with the spike in China's interest in Nepal, which further increased after the Tibetan protests during the Beijing Olympics in 2008. Some argue that the evolving Indo-US relationship also played its part. China's engagement in 
Nepal is either directly correlated with India's action vis-à-vis China, or completely independent of the same. In either scenario, India's strategy to keep Nepal's engagement with China to a minimum is no longer a viable option (Orton,2010).

In the case of an India-China war, it is uncertain whether Nepal will take India's side as per the spirit of the 1950 treaty (as well as subsequent treaties), given Nepal's reluctance to do so in the past. While, on paper, Nepal remains an ally of India, it has constitutionally asserted that its foreign policy is based on the Charter of the United Nations, non-alignment, principles of Panchsheel (and) international law. Major parties have often reiterated this, and the overall national spirit reflects Nepal's desire to remain neutral, as it did during the Doklam standoff in mid-2017 (Donnell,2018).

Moreover, the sheer scale of China's plan and its economic clout is shifting the tide of global order. The US position in Latin America increasingly resembles India's current situation vis-à-vis Nepal. So much so that Panama, once considered to be America's "colony," has now ended its relations with Taiwan upon Beijing's request. El Salvador has done the same. Now, the 60th annual meeting of Inter-American Development Bank, headquartered in Washington D.C., is going to be held in Chengdu, China. The bank's board made this decision despite several warnings from then Secretary of State Rex Tillerson.

Finally, India's stance on Oli's government puts it in an undue negative light. PM of both countries had established a relationship of trust, negotiating some important agreements during their visits. The agreement on the historically controversial Arun III hydel project, and their cooperation in revitalizing BIMSTEC (or the Bay of Bengal Initiative for Multi-Sectoral Technical and Economic Cooperation), are some of the indicators of Nepal's good intentions regarding India.

\section{Opportunity}

The Chinese engagement in Nepal goes beyond the political domain. At a meeting between the then Defense Minister and the Deputy Commander of the PLA, Lieutenant General Ma Xiaotian, held in Kathmandu in December 2008 and signed an agreement on military assistance worth US\$ 2.6 million, which was discussed in September 2008, for the modernization of the NA. That was the first such military assistance to the Maoist government. Beijing had keenly supported the Maoist government's proposal to integrate some 19,000 Maoist guerrillas into the Nepalese Army. China announced a one-time grant of \$20 million, for the rehabilitation of former Maoist combatants. Chinese reiterated their keenness to provide military modernization assistance to Nepal. During the then Chinese Army Chief General Chen Bingde's visit to Nepal and China signed an agreement for providing military aid to the tune of US\$7.7 million to the Nepalese Army in an effort towards deepening the military relations. China's engagement with the Nepalese Army, which has been traditionally close to the Indian and the US Armies, "underlines that China has no 'favorites' on the Nepalese political landscape and has only 'interests' and Beijing will advance its interests no matter who it has to deal with or what it takes. 
China's wooing of Nepal as a new strategic partner has been confirmed by various Chinese officials. Foreign Minister Yang Jiechi said that China would prefer to work with Nepal on the basis of 'strategic partnership, comprehensive partnership of cooperation' and the two countries agreed to further strengthen political and economic ties. Exchange of high-level visits; cooperation in trade and investment, agriculture, transportation, information technology, infrastructure development, hydropower construction and poverty alleviation; cooperation in areas of security, education, human resource development, tourism and cultural exchanges; cooperation between the CPC and various political parties of Nepal; and close coordination and cooperation on major global issues like global financial crisis, climate change, energy, food security border security have been identified for the partnership area for Nepal and China (Sigdel,2018).

\section{The Trans-Himalayan Railway}

China and Nepal have agreed to "intensify implementation of the MoU on Cooperation under the BRI to enhance connectivity, which includes ports, roads, railways, aviation and communications in the framework of the Trans-Himalayan Multi-Dimensional Connectivity Network. India poses a legitimate question: Is the trans-Himalayan railway up to Kathmandu economically viable, since several costly tunnels are needed before the railway reaches the lower mountains and plains? India might be overplaying the risk.

First, excluding Kathmandu, the Chinese Qinghai-Tibet railway already fully operational up to Shigatse (Xigaze) is expected to soon reach the Nepal border(Rasuwagadi) in Kerung (Gyirong). From Kerung it will be a 100-km-long railway to Kathmandu. A combined transportation system of rail and truck via that route reduces the journey substantially; China has already started sending cargoes on freight train from Lanzhou to Kathmandu via Shigatse, where the merchandise is loaded on trucks. The whole journey takes only 10 days, much less than the 35 days it takes through the maritime route via Kolkata. A Chinese railway in Kerung can thus elevate Sino-Nepal trade and commerce (Map-1).

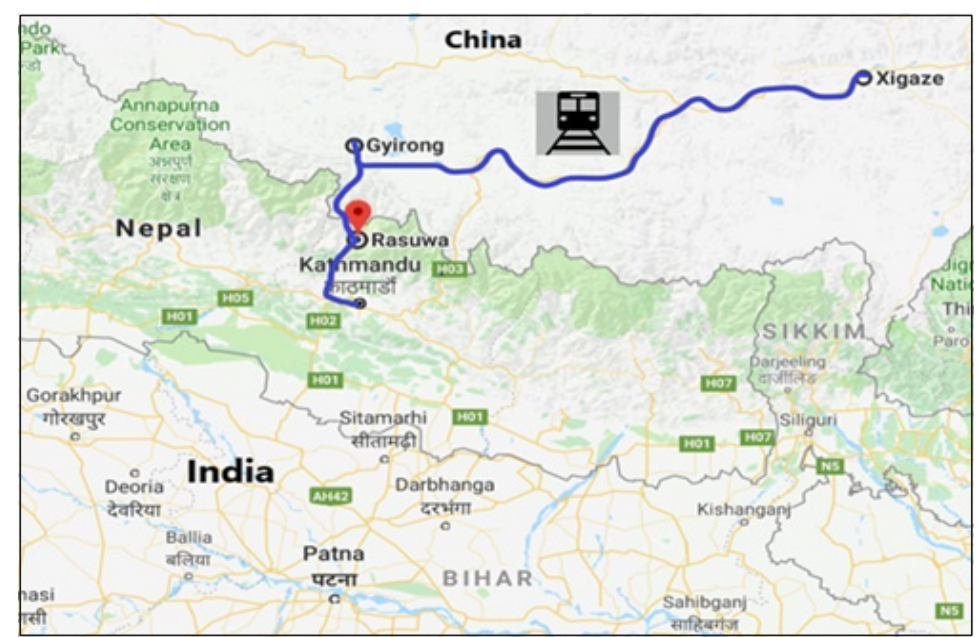

The planned extension of the Qinghai-Tibet railway to Kerung (Gyirong) and into Nepal.

Source: Author's own, based on Google Maps. 
Second, the economic viability of the Kerung-Raxaul (India) route is uncertain, with India emphasizing its own centrality in the project and China planning to reach out to the Gangetic plains via Nepal. For its part, Nepal views the Chinese railway as an opportunity to bring Chinese pilgrims and tourists to Lumbini, the birthplace of the Buddha, and to the popular valley of Pokhara. Nepal is equally eager about the prospects of being road-connected with Myanmar and Thailand through BIMSTEC as it is with the BRI on the northern front. Therefore, India may want to institutionalize the current approach, which seems to be in the best interest of both) map-2).

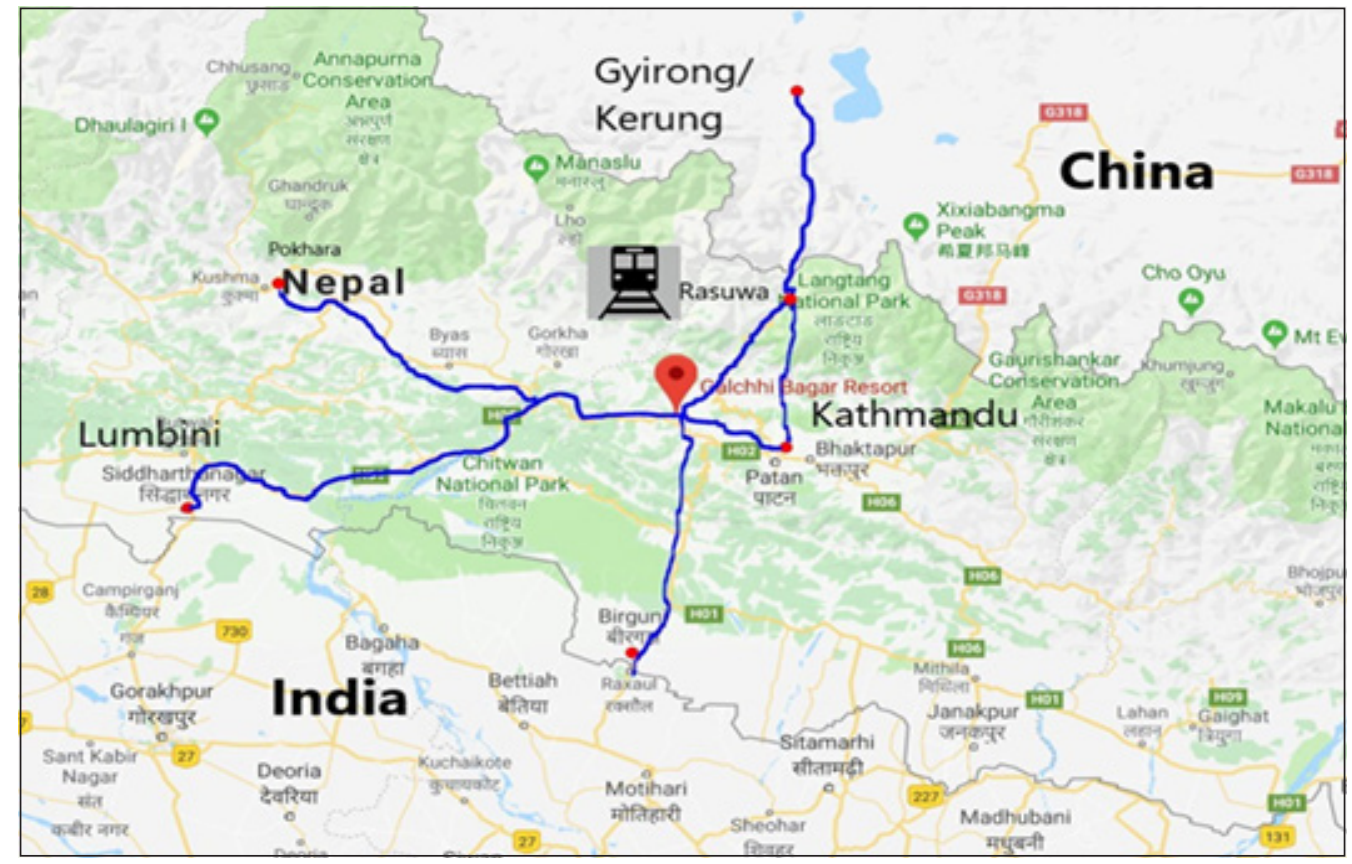

\section{The way forward}

The recent joint communiqués between India and Nepal seem to have all the right words and tone for a constructive move forward in their bilateral relations. Immediately after the successive visits of Modi and Oli to Nepal, there has been unprecedented progress in several areas. For instance, a joint inspection team visited the bordering areas prone to flooding, something that has not happened in the past. Similarly, contrary to expectations, the joint Eminent Persons Group (EPG) has finalized their recommendations on the revision of the 1950 treaty, however, the finalized EPG report has not been submitted yet. PM Modi is not ready to accept the EPG report till now. Another joint meeting has agreed to finalize modalities to implement the grand project of water connectivity, and India is willing to provide financial and technical support. The Nepal government wants ships to enter Nepali waters. The MoU on the Raxaul-Kathmandu railway has also been well-received.

However, despite generous announcements, India continues to send mixed signals. First, in terms of the land and air connectivity, the response has been sluggish: the gap between 
providing access to Vizag Port and new air routes to Nepal is two years. Nepal's request to access India's west ports is at a nascent stage and will take some more years. Second, while Modi has hit all the right chords in his talks. India is still unwilling to cooperate on power trade with Nepal in the way Nepal would to provide electricity at lower rates. The message that Nepal remains India's "client state" will not be helpful to the aims of working towards a higher level of cooperation. India must formulate an integrated approach towards Nepal to reflect the current reality.

Regarding China's inroads into Nepal, an option for India would be to defend the status quo by attempting to block Nepal's options to diversify its cooperation with neighbors, through projects such as the infrastructure development by Chinese investment. However, such a policy is bound to fail because Nepal is determined to take advantage of cooperation opportunities with foreign partners, including China. Addressing the issue of external interference. Foreign Ministry of Nepal tries to draw a clear boundary line, stating that internal matters would never be the issues in a bilateral discussion with India, China and others.

China is winning hearts and minds in Nepal through generous strategic charity. After the 19th Party Congress, it will continue to "use economic diplomacy as the foundation of its foreign policy. Therefore, the way forward for India would be to depart from its exclusively traditional security angle and be proactive with innovative strategies and policies. The first step is to identify the major cause of Nepal's behavior towards India. Why has the Nepali establishment consistently resisted India while being so welcoming to China? This is a particularly crucial question, since Nepal has growing trade deficits with both countries. Second, India must introduce new economic, developmental and infrastructure initiatives with Nepal that will not only bring tangible benefits to Nepali citizens but also address the vulnerabilities that will emerge in Nepal as the country engages with China. However, India tries to deliver on its promises comes from its awareness of India's own need to keep Nepal closer to itself than China.

As things are, Nepal cannot dispense with its reliance on India. India is and will remain vital for the country in many ways. However, Nepal is now a member of China's massive BRI, which puts India in a difficult position. New Delhi has found itself utterly unprepared to deal with an assertive Chinese foreign policy under Xi Jinping. India must figure out where it stands vis-à-vis Nepal and what is the way for forward in the short, medium and long term, given the shifting regional and global structure, technological breakthroughs, as well as new threats such as terrorism. Nepal, for its part, has lived through a historic political transformation but continues to face huge challenges in terms of managing its population and economy; remittance makes up to about 30 percent of the country's GDP and mostly originates in the Gulf. There is an increasingly strong Nepali diaspora in many parts of the world. Therefore, India and Nepal must figure out in what new ways they can move forward in the best interest of both parties.

Analysts are not entirely accurate in their apprehensions about Nepal's independent foreign relations. A strongly sovereign Nepal is beneficial, not detrimental, to India's 
security. Nepal shares a 1,400-km-long border with the Tibetan Autonomous region of China, perhaps the only section in the Himalayas where there are no security threats. In a way, Nepal has helped India avoid the need to deploy thousands of troops and military hardware to this extra $1,400 \mathrm{~km}$ for its force posturing. India has had to do so along the 4,000 km China border, which too has not deterred China from building infrastructure on contested land Doklam being a case in point. Emphasizing Nepal's sovereign status and independent policy choices, and helping Nepal exercise these is in India's interest. Similarly, there are concerns in some quarters of Kathmandu about the possible trilater al or $2+1$ cooperation, that Nepal's sovereign interests are being undermined in the India-China deals. It will help build trust if India manages to translate its good will into meaningful action.

As long as the principles of non-interference and peaceful co-existence are respected and a high level of political engagement is pursued, there will increasing cooperation in Modi's initiatives, which would have been impossible just a year ago.be bonhomie and cooperation between the leaders of India and Nepal. At the same time, it will assuage China's unease about its security in Nepal. Disregarding India's traditional muscular diplomacy, PM Modi seems to have been following this line of cooperative diplomacy.

\section{Conclusion}

Nepal's international relations and foreign policy have shaped by its geospatial context and links between India and China in different political as well as economic nodes in which diverse and dense global political economic networks are regulated by USA, China, India and European Union. Both China and India are emerging and want to catch up the westerns including other developed countries. Where USA wants to show leadership by offering technological help to the emerging economies through its Millennium Challenge Corporation (MCC) agenda under the Indo-Pacific Strategy in Asian countries. It is. therefore, the ongoing political, economic and military strategies of powerful nations including both China and India, Nepal has to adopt among equals diplomatic relation and to take maximum economic and technological benefits from global major and emerging regional powers through domestic territory-based exercises of unified national power. Thus, Nepal has to be followed world balance foreign relation strategy in the face of dynamic changes in the 21 st century i.e. global century.

\section{References}

Cohen, S.B. (2010). Geopolitics: The geography of international relation. 2 nd ed. New York: Rowman \& Littlefield Publishers INC.

Dixit,K.(2010).A New Himalayan Game., The Fletcher Forum of World Affairs, 34(1), Winter at http://www.india-seminar.com/2008/584/584_srinath_raghavan.htm (accessed on July 2020).

Donnell; F. O.' (2018). Stabilizing Sino-Indian security relations: managing the strategic rivalry after Doklam. New Delhi: Rawat Publication 
Ghimire,Y.(2012). Big Power Deal Gives Chinese a Foothold in Nepal. Straits Times Indonesia, 10 March 2012, at http://www.thejakartaglobe.com/economy/big-pow er-dealgives-chinese-a-foothold-in-nepal/503811(accessed on August2020).

Muni, S.D. \& Tan Tai Yong (eds). (2011). A Resurgent China: South Asian Perspectives. New Delhi: Routledge.

Nayak,N.R.(2014). Strategic Himalayas: Republican Nepal and External Powers. New Delhi: Institute for Defense Studies and Analyses. ISBN 978-81-8274-761-6

Orton, A.(2010). India's Borderland Disputes: China, Pakistan, Bangladesh and Nepal. New Delhi: Epitome Books.

Pande, A. (2011). India's Nepal Policy. Accessed on March 31, 2020 from https://www.hudson.org/research/7615-india-s-nepal-policy

Pant, H. V. \& Rei, A.(2018).Is India ready for the Indo-pacific?” The Washington Quarterly 41, no. 2 (2018), 47-61.

Rajan, K.V. (2018)., Should the 1950 treaty be scrapped? The Hindu, access at https://www.thehindu.com/todays-paper/tp-opinion/Should-the-1950-treaty-bescrapped/article15215112.ece.

Shrestha, B. N. (2014.). The natural environment and the shifting Borders of Nepal. Slavic-Eurasian Research Center. Retrieved from http://src-h.slav.hokudai. ac .jp/ publictn/eurasia_border_review/Vol42/V4N204Shrestha2.pdf

Sigdel,A.(2018) China's growing footprint in Nepal: challenges and opportunities for India. Issues Briefs and Special Reports.at http:/www. Issue briefs(accessed on August 2020) 